\title{
Grazing impact on chromophoric dissolved organic matter (CDOM) by the larvacean Oikopleura dioica
}

\author{
Juanita Urban-Rich ${ }^{1, *}$, Diego Fernández ${ }^{2}$, José Luis Acuña ${ }^{2}$ \\ ${ }^{1}$ Environmental, Coastal and Ocean Sciences, University of Massachusetts Boston, 100 Morrissey Boulevard, \\ Boston, Massachusetts 02125, USA \\ ${ }^{2}$ Área de Ecología, Departamento de Biología de Organismos y Sistemas, Universidad de Oviedo, \\ C/Catedrático Rodrigo Uría (S/N), Oviedo 33071, Spain
}

\begin{abstract}
Experiments were conducted to determine if the pelagic larvacean Oikopleura dioica could graze on chromophoric dissolved organic material (CDOM) and if so, could such grazing affect the optical characteristics of the water column. Although $O$. dioica was found to graze on CDOM, it also contributes to the CDOM pool. $O$. dioica cleared large, $>10 \mathrm{kDa}$ CDOM, with clearance rates ranging from $0.5 \mathrm{ml} \mathrm{d}^{-1}$ for humic material to $8.9 \mathrm{ml} \mathrm{d}^{-1}$ for proteins suggesting a differential cycling of dissolved organic material by this larvacean. Its excretion of CDOM was in the $<5 \mathrm{kDa}$ size range. The clearance of large-sized CDOM ( $>10 \mathrm{kDa})$ and the excretion of small-sized CDOM $(<5 \mathrm{kDa})$ resulted in an alteration of the molecular size distribution of the CDOM in natural seawater. Thus the relationship between grazing removal and excretion inputs will affect the cycling and molecular size distribution of CDOM and influence water color.
\end{abstract}

KEY WORDS: Oikopleura dioica $\cdot \mathrm{CDOM} \cdot$ Grazing $\cdot$ Water column $\cdot$ Water color

\section{INTRODUCTION}

Oikopleuridae are pelagic tunicates that are nonselective filter-feeders, feeding on particles ranging from 0.3 to $>30 \mu \mathrm{m}$ (Flood 1978, Flood et al. 1992, Bedo et al. 1993). Oikopleurids live in transparent, gelatinous houses that serve as elaborate particle traps through which they pump water and from which they suck particle-enriched water into their pharynx (e.g. Alldredge 1977, Flood 1991). Flood (1991) estimated that the food-concentrating chamber of the house allowed the oikopleurid to feed on approximately 1000× concentrated suspension of particles. Later, Morris \& Deibel (1993) measured concentration factors ranging from 74 to 1089 , with higher values associated with smaller individuals. This concentrating mechanism of feeding could possibly lead to the ingestion of dissolved material either through the formation of larger colloids during concentration or through direct interception of the dissolved material with the filter apparatus.
Little is known about the relationship between oikopleurids and dissolved organic matter (DOM), but it has been suggested that they could be important in the flux of DOM and in the size distribution of DOM (Gorsky \& Fenaux 1998). Because of the small size range of particles that they consume, they have been considered important regulators of bacterioplankton (Alldredge 1977, Fernandez \& Acuña 2003) and thus the cycling of DOM by bacteria. In addition, the ability of oikopleurids to filter colloidal material has been demonstrated (Flood et al. 1992), and since much of the terrestrial DOM is in the high molecular weight range (Cauwet 2002) they could potentially directly consume this material and repackage it into biomass or rapidly sinking fecal pellets. Nothing is currently known about the excretion of DOM by oikopleurids.

DOM is a complex pool comprised of many different types of compounds. One significant component of DOM is chromophoric dissolved organic matter (CDOM). CDOM is important because it has the unique characteristic of absorbing ultraviolet and visible light, 
thereby affecting the optical characteristics of the water column (Kalle 1966, Arrigo \& Brown 1996). The fluorescent characteristics of CDOM allow detection of small amounts of material, permitting CDOM to be used as a tracer (Zimmerman \& Rommets 1974, de Souza Sierra et al. 1997). In addition changes in its fluorescent spectral characteristics can also be used to identify source materials (Coble 1996, McKnight et al. 2001). The majority of the CDOM is derived from terrestrial sources, so highest concentrations are found in coastal waters and decrease with increasing distance from the shore (Blough et al. 1993). Physical mixing, photo-oxidation and bacterial remineralization (Cabaniss \& Shuman 1987, Skoog et al. 1996, De Souza Sierra et al. 1997, Moran \& Zepp 1997, Moran et al. 2000) have been the only avenues explored to explain the cycling and removal of CDOM. We hypothesized that the pelagic larvacean Oikopleura dioica could clear CDOM from the water by means of its unique filtration system. Since these larvaceans can occur at high concentrations in neritic waters (Dagg 1995), if they can graze on CDOM they might affect the water color.

The objective of this study was to examine the grazing effects of Oikopleura dioica on colored dissolved organic matter (CDOM) to determine (1) if they can filter CDOM from the water, and (2) if their grazing changes the fluorescent characteristics or molecular weight distribution of the CDOM. The fluorescent characteristics of CDOM make this a good tracer in grazing experiments and allow for experiments with naturally occurring CDOM. In addition, fluorescent excitation-emission matrices allow for the detection of changes in fluorescent pools that can suggest different source materials.

\section{MATERIALS AND METHODS}

Laboratory experiments were conducted with the cultured appendicularian Oikopleura dioica at the University of Oviedo in northern Spain. Appendicularian cultures were started in spring 2001 with individuals collected from El Musel harbor in Gijon. The appendicularians were cultured in 51 glass jars filled with $30 \mu \mathrm{m}$ filtered seawater mixed with a Plexiglas spiral paddle rotating at $10 \mathrm{rpm}$ (Fenaux and Gorsky $1979,1985)$ in a temperature-controlled room at $15^{\circ} \mathrm{C}$. The appendicularians were sorted according to size and transferred into freshly filtered $(30 \mu \mathrm{m})$ seawater every $3 \mathrm{~d}$ using a wide-bore pipette. Only large adult (avg. trunk length $710 \mu \mathrm{m}$ ) O. dioica were used in the grazing experiments.

Grazing on $30 \mu \mathrm{m}$ filtered seawater. Grazing experiments were conducted to examine the impact of Oikopleura dioica on CDOM composition of natural seawater. Adult $O$. dioica were preconditioned for $4 \mathrm{~h}$ in
$30 \mu \mathrm{m}$ filtered seawater collected from El Musel Harbor. We filled 3 treatment and control, $100 \mathrm{ml}$ acidwashed, amber glass bottles with $90 \mathrm{ml}$ of $30 \mu \mathrm{m}$ filtered seawater. The appendicularians were then rinsed with $0.2 \mu \mathrm{m}$-filtered seawater and $50 \mathrm{O}$. dioica were added to each of the 3 treatment bottles and an equivalent volume $(10 \mathrm{ml})$ of the $0.2 \mu \mathrm{m}$ rinse-water was added to the control bottles. The bottles were rotated $(0.5 \mathrm{rpm})$ on a plankton wheel in the dark for $1 \mathrm{~h}$ at $15^{\circ} \mathrm{C}$ in a temperature-controlled room. At the end of incubation, samples were taken for absorption and fluorescence of CDOM and bacterial abundance (see following subsections).

Samples were also taken to examine the molecular weight distribution of the colored dissolved fraction. Water from the treatment and control bottles was first filtered through a $0.2 \mu \mathrm{m}$ polycarbonate filter and the filtrate was fractionated into $<30$ and $<5 \mathrm{kDa}$ using acidcleaned, Centricon Plus-20 tubes. Milli-Q water was used as a blank and the fluorescence in the blank was subtracted from the samples to correct for any addition arising from absorption onto the tube walls. A total of 15 $\mathrm{ml}$ of sample water was spun for $15 \mathrm{~min}$ at $4000 \times \mathrm{g}$ at $15^{\circ} \mathrm{C}$ on Jouan MR1812 centrifuge with a fixed rotor. The retention efficiency (RE) of the tubes was determined by using fluorescently stained dextrans from molecular probes with reported molecular weights of 5000 and $30000 \mathrm{Da}$. The RE of the $30 \mathrm{kDa}$ tubes was $97 \%$ and that of the $5 \mathrm{kDa}$ tubes was $88 \%$. The filtrate and retentate were stored in frozen amber glass vials for later analysis of fluorescence and absorption.

Tracer experiment. Tracer experiments were conducted to determine if Oikopleura dioica was able to filter and ingest dissolved organic material and, if so, in what size range. Mixtures of fluorescent dextrans from molecular probes (http://probes.invitrogen.com/) were used in 2 separate experiments. The first treatment mixture (Tracer 1/Expt 1) consisted of dextrans with molecular weights of 3 and $40 \mathrm{kDa}$ at a concentration of $2.5 \mu \mathrm{M}$ in $0.2 \mu \mathrm{m}$ filtered seawater. The second treatment mixture (Tracer 2/Expt 2) consisted of 10 and $70 \mathrm{kDa}$ dextrans at a concentration of $2.5 \mu \mathrm{M}$ in $0.2 \mu \mathrm{m}$ filtered seawater. The tracer solutions were filtered through a $0.2 \mu \mathrm{m}$ polycarbonate filter prior to the experiment to remove any aggregates.

The experimental design consisted of six, $40 \mathrm{ml}$ amber vials filled with the tracer solution and 20 Oikopleura dioica in houses, 6 vials filled with the tracer solution and 20 empty $O$. dioica houses, and 6 vials filled only with tracer solution. The 2 control sets were designed to measure passive absorption onto the $O$. dioica houses and vial walls. Each vial was incubated for $5 \mathrm{~min}$ on a rotating plankton wheel. Since the object of the experiment was to determine if oikopleurids could filter and ingest the dissolved tracers 
and to calculate the clearance rates of each tracer, experiments were restricted to $5 \mathrm{~min}$ to prevent excretion of the tracer. Previous work had shown that 5 min incubations allow significant uptake, but are shorter than the gut-passage time of the appendicularian, and thus do not change its functional ingestion rates or behavior (Acuña \& Kiefer 2000). The appendicularians and houses or houses alone were transferred 3 times, using a wide-bore pipette, into $0.2 \mu \mathrm{m}$ filtered seawater to rinse any extra label off the outside of the house. Appendicularians and houses were then immediately frozen in liquid nitrogen until they could be examined by fluorescent microscopy. Samples from the rinse-water and from the vials were taken for spectrofluorometric analysis.

Clearance rates were calculated for each of the treatments $(3,10,40$ and $70 \mathrm{kDa})$ using the methods of Acuña \& Kiefer (2000) (see Table 2). Briefly, the change in fluorescence in the treatment bottles (corrected for any loss in the control bottles) compared to the initial fluorescence in the water was divided by the number of individuals per vial and incubation period. This value was then converted into standard units of $\mathrm{ml}$ ind. ${ }^{-1} \mathrm{~d}^{-1}$.

Natural CDOM experiment. Grazing experiments on different size fractions of naturally occurring CDOM were conducted to determine if Oikopleura dioica could remove CDOM and thereby influence the optical characteristics of the water. Water was collected from a local estuary in northern Spain and filtered through a $0.2 \mu \mathrm{m}$ Supour Cup Filter (GelmanScience SuporCap 100) that was acid-washed and rinsed with 201 of Milli$\mathrm{Q}$ water prior to collecting the CDOM water. The water was size-fractioned, the 4 size fractions comprising material $>30,<30,>5$ and $<5 \mathrm{kDa}$. The concentrates were prepared by adding $10 \mathrm{ml}$ to 30 and $5 \mathrm{kDa}$ Centricon Plus-20 centrifuge tubes and spinning at $4000 \times g$ for 10 min on a Jouan MR1812 Centrifuge with a fixed rotor. The $<30$ and $<5 \mathrm{kDa}$ filtrates were collected and placed in combusted $40 \mathrm{ml}$ scintillation vials for use as experimental water. The $<30$ and $<5 \mathrm{kDa}$ filtrates were not diluted, and were used directly in the incubation vials. The retentate was collected by inverting the tubes and spinning them for $3 \mathrm{~min}$ at $1000 \times \mathrm{g}$. The process was repeated until $10 \mathrm{ml}$ of retentate had been collected in both the 30 and $5 \mathrm{kDa}$ tubes. We added $10 \mathrm{ml}$ aliquots of CDOM retentate ( $>30$ and $>5 \mathrm{kDa}$ ) to $120 \mathrm{ml}$ of photo-oxidized $0.2 \mu \mathrm{m}$ filtered seawater to prepare 2 treatments with CDOM fractions of different size.

Twelve $20 \mathrm{ml}$ scintillation vials were used with 6 vials containing appendicularians in houses and 6 control vials with only CDOM-enriched seawater. Similar to the tracer experiment, incubations lasted only $5 \mathrm{~min}$ and the vials were rotated on a plankton wheel. The oikopleurids were picked out of the vial and trans- ferred into 2 sequential vials with $0.2 \mu \mathrm{m}$-filtered seawater for rinsing, and were then frozen in liquid nitrogen. This protocol was followed for each of the 4 size fractions of CDOM. Water samples for fluorescent spectrophotometry were taken.

Clearance rates of the humic and protein fractions were calculated wherever possible, as described previously for the tracer experiment. (For average clearance rate of all humic components [Peaks A, C and M combined] see Table 2).

Water analysis. Samples for CDOM absorption and fluorescence were collected by filtering 70 to $200 \mathrm{ml}$ of water through a $0.2 \mu \mathrm{m}$ Nuclepore filter. The filtrate was stored frozen in amber vials for analysis in the laboratory. All samples were analyzed within 2 mo of collection and no significant changes in absorption of fluorescence were observed within that time frame (J. Urban-Rich unpubl. data). CDOM absorption was measured on a Carey 50 spectrophotometer using a $10 \mathrm{~cm}$ cuvette, and corrected with a Milli-Q blank. Absorption coefficients at $355 \mathrm{~nm}$ were calculated as described by Green \& Blough (1994). This value was chosen as it is the most commonly used and thus allowed us to compare our results with literature values. Spectral slopes (S) were determined by linear, least-squares regression based on the exponential decay relationship of:

$$
a(\lambda)=a\left(\lambda_{0}\right) \mathrm{e}^{-S\left(\lambda-\lambda_{0}\right)}
$$

where $a(\lambda)=$ absorption at a desired wavelength ( $355 \mathrm{~nm}$ is the usual value for CDOM), $\lambda_{0}=280 \mathrm{~nm}$ (the initial wavelength), and $S$ is the fitted parameter for the exponential decay of $a(\lambda)$ with increasing $\lambda$. Thus, $S$ describes the rate of decrease in CDOM absorption with increasing wavelength. $S$ varies with the source of CDOM, and changes in $S$ can reflect biological or chemical modifications of CDOM.

CDOM fluorescent excitation-emission matrices were measured on a SPEX FluoroMax-3. Excitation (ex) scans from 250 to $550 \mathrm{~nm}$ at $5 \mathrm{~nm}$ intervals and emission (em) scans from 265 to $710 \mathrm{~nm}$ at $2 \mathrm{~nm}$ intervals and $2 \mathrm{~s}$ integration created 61 individual excitation-emission scans. Slit widths were $5.0 \mathrm{~nm}$ for excitation and $2.0 \mathrm{~nm}$ for emission. The instrument was corrected as per the manufacturer's instructions. Data were normalized to the water Raman Peak at ex/em $=350 / 397 \mathrm{~nm}$ and converted into quinine sulfate units (QSU) using a correction curve generated with a quinine sulfate standard in $0.05 \mathrm{M}$ sulfuric acid (Coble et al. 1993).

Fluorescent excitation-emission matrix scans (EEMS) can give information on different humic and protein components of the CDOM pool. Regions within EEMS have been defined by Coble (1996) as humic-like or protein-like (Table 1). In order to compare our data 
Table 1. Major fluorescent components of seawater defined by Coble (1996) compared with those found in present study (Figs. 2, 3 \& 7). Coble's maximum excitation/emission (ex, em) values taken as standard

\begin{tabular}{|c|c|c|c|c|c|}
\hline \multirow[t]{2}{*}{ Peak } & \multicolumn{2}{|c|}{ Coble (1996) } & \multicolumn{2}{|c|}{ Present study } & \multirow{2}{*}{ Description } \\
\hline & $\mathrm{ex}_{\max }$ & $\mathrm{em}_{\max }$ & $\mathrm{ex}_{\max }$ & $\mathrm{em}_{\max }$ & \\
\hline B & 275 & 310 & 275 & 315 & $\begin{array}{l}\text { Tyrosine-like, } \\
\text { protein-like }\end{array}$ \\
\hline $\mathrm{T}$ & 275 & 340 & 275 & 340 & $\begin{array}{l}\text { Tryptophan- } \\
\text { like, } \\
\text { protein-like }\end{array}$ \\
\hline $\mathrm{A}$ & 260 & $380-460$ & 250 & 440 & Humic-like \\
\hline M & 312 & $380-420$ & 325 & $418-440$ & $\begin{array}{l}\text { Marine humic- } \\
\text { like }\end{array}$ \\
\hline $\mathrm{C}$ & 350 & $420-480$ & 350 & 450 & Humic-like \\
\hline
\end{tabular}

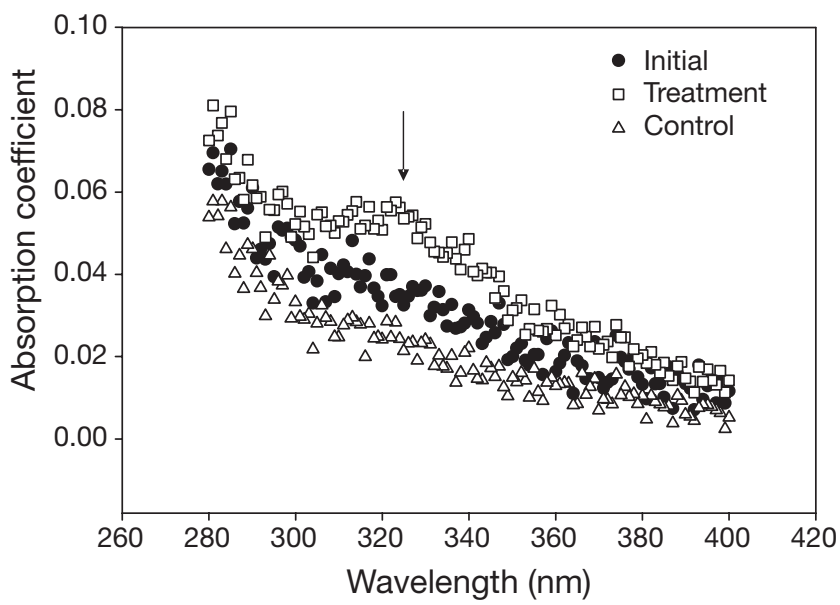

Fig. 1. Oikopleura dioica. Average CDOM absorption in grazing experiment using $30 \mu \mathrm{m}$ filtered seawater. See 'Materials and methods' for explanations of treatments. Arrow indicates region where there was significant increase in absorption in treatment bottles with other published data, we have used these same notations for the peak regions, although slight changes in excitation and emission maximums were observed in our study. Changes in the region of maximum peak intensity for Humic Peaks M and C and the fluorescent proteins were monitored in each experiment.

We preserved 5 to $25 \mathrm{ml}$ of water from each sample and control bottle with $0.1 \%$ gluteraldehyde for bacteria counts. The water was gently filtered onto a black Poretics $0.2 \mu \mathrm{m}$ membrane filter and stained with acridine orange (Hobbie et al. 1977). Slides were frozen until counted in the laboratory with epifluorescent microscopy.

\section{RESULTS}

\section{Grazing on natural seawater}

Grazing experiments conducted with the pelagic larvacean Oikopleura dioica revealed it to be a source of CDOM. Significant increases in CDOM absorption at $355 \mathrm{~nm}\left(a_{355}\right)$ were detected in the treatment $(\mathrm{T})$ bottles compared to the initial (I) and control (C) bottles $\left(\mathrm{I}_{\mathrm{abs}}=\right.$ $0.43 \pm 0.03 \mathrm{~m}^{-1}, \mathrm{~T}_{\mathrm{abs}}=0.56 \pm 0.05 \mathrm{~m}^{-1}, \mathrm{C}_{\mathrm{abs}}=0.28 \pm 0.09$ $\mathrm{p}<0.05)$. An examination of all the absorption data revealed a peak around $320 \mathrm{~nm}$ (Fig. 1) which caused $\mathrm{S}$ to decrease in the treatment bottles (for I, $s=6.5 \times$ $10^{3}$, for $\mathrm{C}=6.8 \times 10^{3}$, for $\mathrm{T}=6.0 \times 10^{3} \mathrm{~nm}^{-1}$ ). An examination of the EEMs revealed a strong increase in the region of Peak M (ex/em 320/420 nm) fluorescence (Fig. 2) that corresponded with the hump in the absorption data (Fig. 1).

Analysis of the molecular weight distribution of the fluorescent material in the grazing experiment indicated that the humic material (average ex/em 320/420
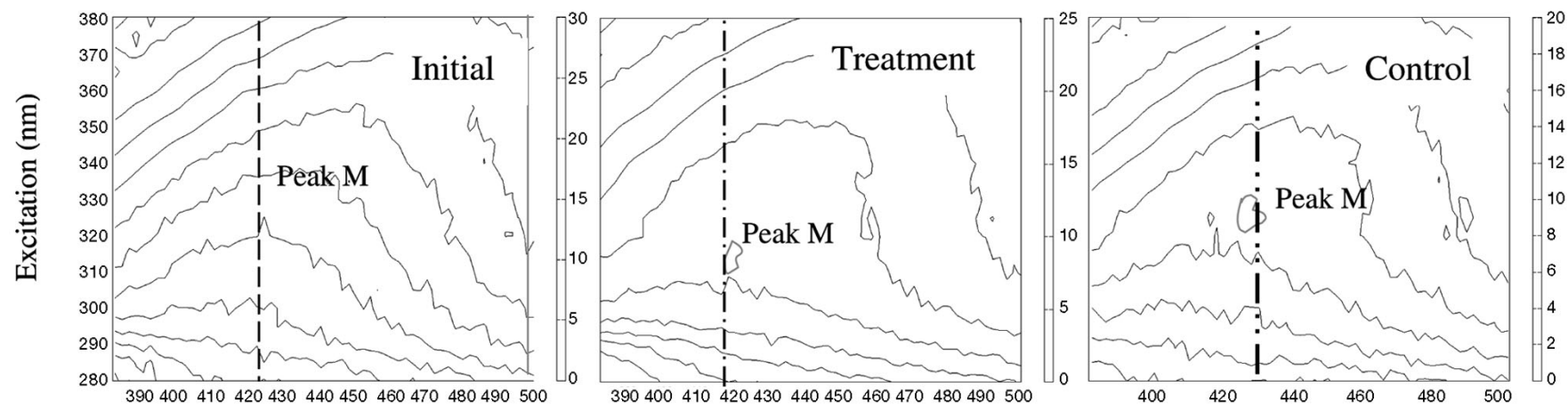

Emission (nm)

Fig. 2. Oikopleura dioica. Excitation (ex)-emission (em) (3D) scans from the grazing experiment using $30 \mu \mathrm{m}$ filtered seawater. Scale bar on right of each graph is in normalized quinine sulfate units (QSU). Peak M: humic Peak M region (maximum ex/em in treatments was at 320/420 nm). Peak M values increased by 1.3 in treatment bottles (2.1 QSU) compared to initial values (1.5 QSU) and control bottles (1.50 QSU); however, maximum peak region shifted to blue in treatment bottles (maximum intensity represented by dotted/dashed lines) and total peak region broadened 
and 280/420 $\mathrm{nm}$ ) added by Oikopleura dioica was $<30 \mathrm{kDa}$ (Fig. 3). In addition, the added protein material was primarily in the 5 to $30 \mathrm{kDa}$ range. However, there was a loss of protein material and humic material in the $>30 \mathrm{kDa}$ range.

Bacterial numbers decreased slightly in the treatment bottles and increased in the controls (Fig. 4). The increase in bacterial numbers in the control bottles may explain the slight decrease in CDOM absorption in the control bottles compared to initial bottles as the bacteria may have degraded some of the CDOM. No significant changes in chlorophyll concentrations occurred in the treatment or control bottles during the $1 \mathrm{~h}$ incubation.

\section{Tracer experiment}

The tracer experiments were run to determine if Oikopleura dioica could ingest DOM. Epifluorescent micrographs of $O$. dioica clearly show the presence of the fluorescent dextrans in the guts and within its fecal pellets, illustrating the ability of $O$. dioica to filter and ingest DOM (Fig. 5). On average, $1 \%$ of the removed tracer adhered to the empty oikopleurid houses and to the vial walls; however for the treatment vials, we corrected for this loss in our calculations. Significant removal of the tracer was detected for the 3,10 and $40 \mathrm{kDa}$ dextrans, but not for the $70 \mathrm{kDa}$ fraction (Fig. 6), with most removal occurring with the 10 and

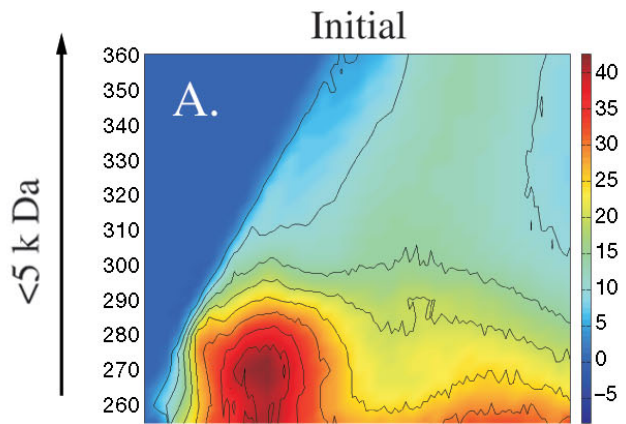

总
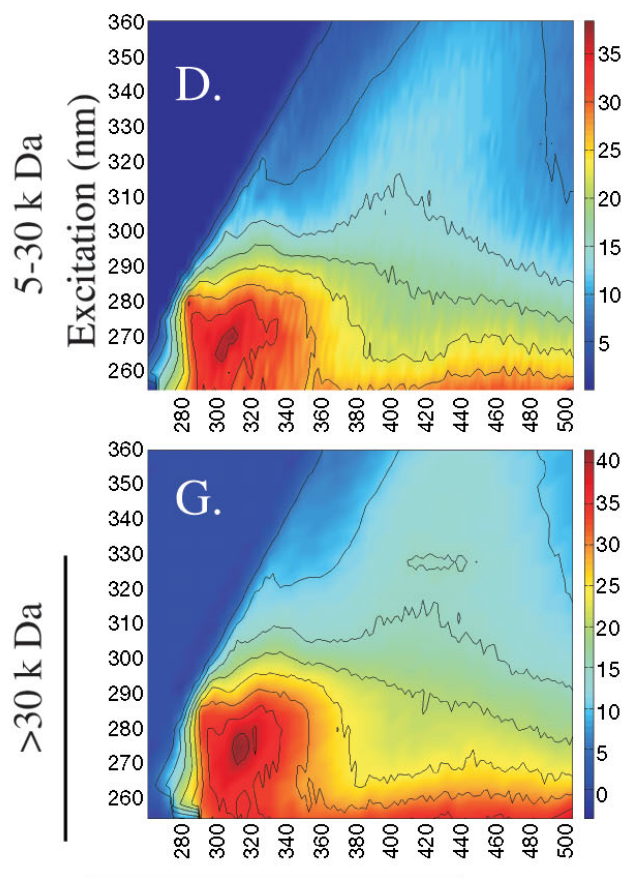

Treatment

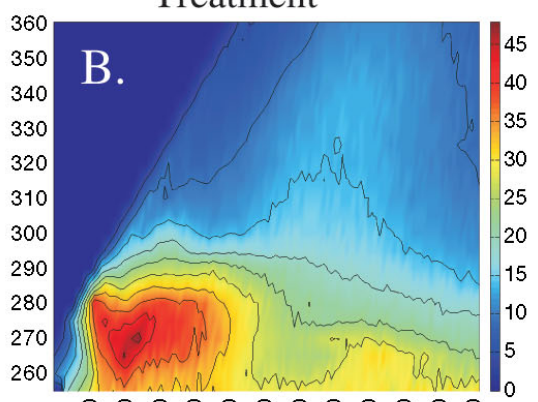

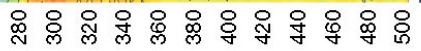

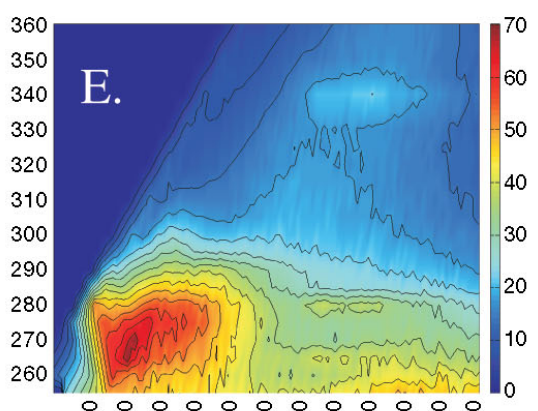

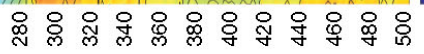

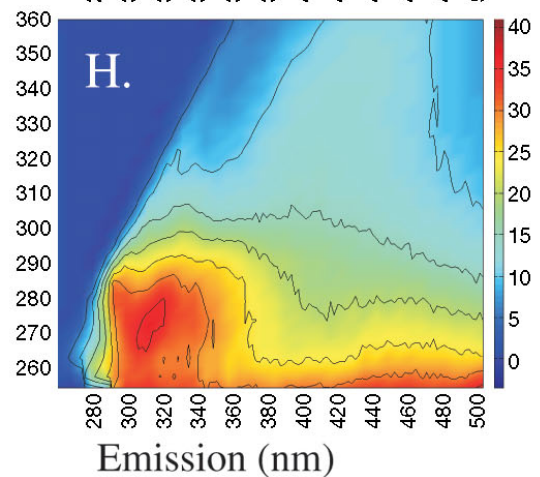

Control

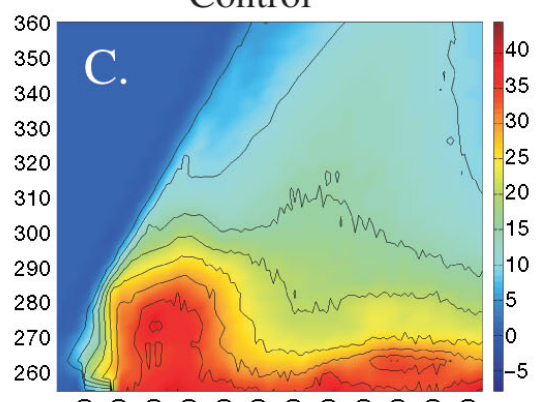

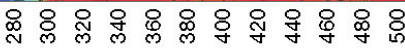

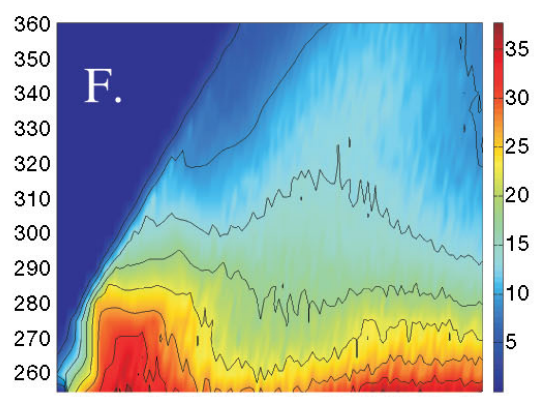

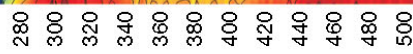

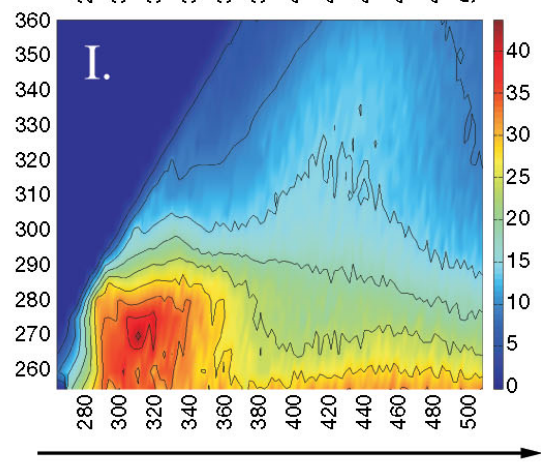

Fig. 3. Oikopleura dioica. Excitation-emission scans of molecular weight fractions from grazing experiment using $30 \mu \mathrm{m}$ filtered seawater. Scale bar on right of each graph is in normalized quinine sulfate units (QSU); $x$-axis is emission range from 270 to $500 \mathrm{~nm}$ in $20 \mathrm{~nm}$ intervals; $y$-axis is excitation range from 250 to $360 \mathrm{~nm}$ in $10 \mathrm{~nm}$ intervals. In filtrate of $5 \mathrm{kDa}$, Humic Peak M (ex/em 320/420 nm) and protein material (ex/em 275/310 and 275/350 nm) increased in treatment bottles (B); in filtrate between 5 and $30 \mathrm{kDa}$, Humic Peak M (ex/em 320/440 nm), region of 280/420 nm, Humic Peak C (ex/em 340/450 nm) and protein region (ex/em 275/300-350 nm) increased in treatment bottles (E); in filtrate of $>30 \mathrm{kDa}$, Humic Peaks C and M decreased in treatment bottles $(\mathrm{H})$, as did protein region of $275 / 350 \mathrm{~nm}$ and area of $280 / 400 \mathrm{~nm}$ 


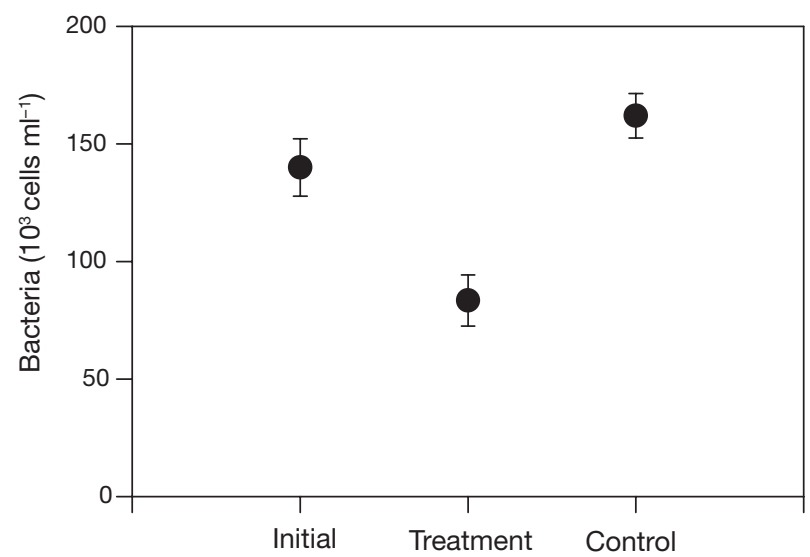

Fig. 4. Bacterial cell abundance during grazing experiment with Oikopleura dioica. Decreases in bacterial numbers were observed in treatment bottles, while slight increases in control bottles were seen

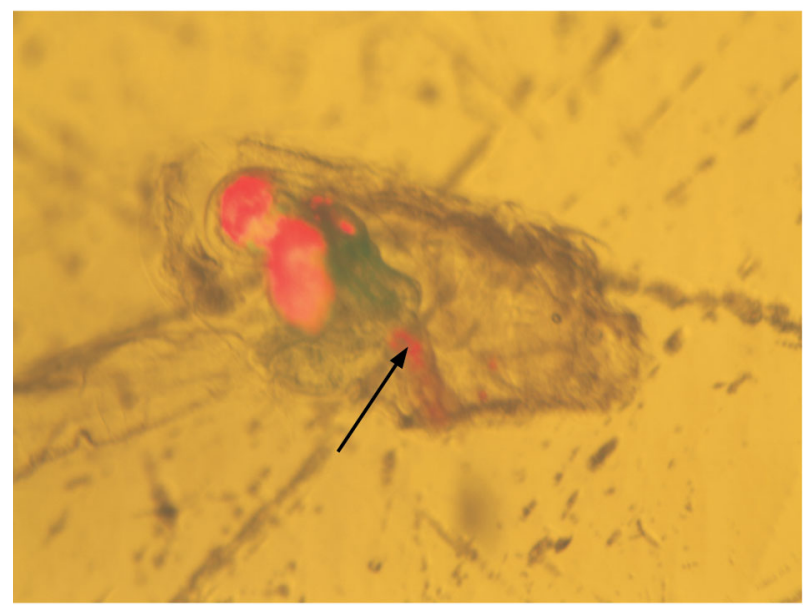

Fig. 5. Oikopleura dioica. Fluorescent dextrans (40 kDa) visible in pharynx (arrowed), gut and fecal pellets after 5 min incubation

40 kDa dextrans ( $\mathrm{p}<0.001$; Wilcoxon paired-sample $T$-test). Estimated clearance rates ranged from 28.4 and $28.9 \mathrm{ml} \mathrm{d}^{-1}$ for the 40 and $3 \mathrm{kDa}$ dextrans to $55.1 \mathrm{ml}$ $\mathrm{d}^{-1}$ for the $10 \mathrm{kDa}$ dextrans for individuals with an average trunk length of $710 \mu \mathrm{m}$ (Table 2).

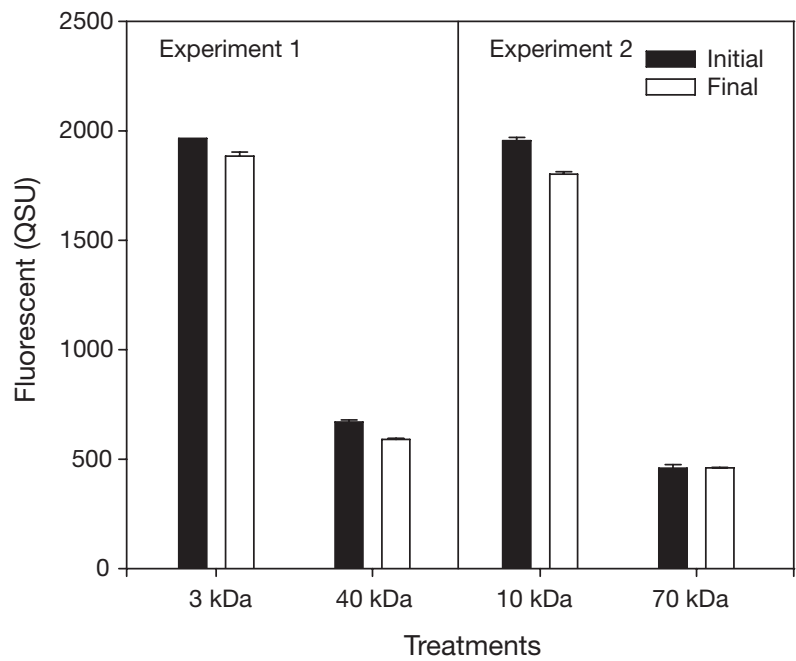

Fig. 6. Oikopleura dioica. Fluorescent dextrans were added to $0.2 \mu \mathrm{m}$ filtered seawater and incubated with appendicularians for 5 min to determine if it could clear and ingest DOM. Significant removal of the 3,10 and $40 \mathrm{kDa}$ tracers occurred ( $\mathrm{p}<0.05, \mathrm{p}<0.001$ and $\mathrm{p}<0.05$, respectively; Wilcoxon paired-sample $t$-test). Treatments corrected for any loss observed in control bottles (loss in controls was negligible, and was not significant in any dextran treatment)

\section{Grazing on natural CDOM}

CDOM is a large pool comprised of many different compounds with different structures, functions, and sizes. Results of the grazing experiment with CDOM collected from a local estuary indicate that Oikopleura dioica can remove material from some size fractions. Significant removal of humic and protein material occurred in the $>30 \mathrm{kDa}$ treatment (Student $t$-test, $\mathrm{p}<$ $0.05)$, highly variable results were recorded in the 5 to $30 \mathrm{kDa}$ treatments, and significant inputs occurred in the humic and protein material in the $<5 \mathrm{kDa}$ treatment (Fig. 7; p < 0.05). Clearance rates for the $>30 \mathrm{kDa}$ fraction ranged from 0.5 to $8.5 \mathrm{ml} \mathrm{d}^{-1}$ for individuals with an average trunk length of $700 \mu \mathrm{m}$, with higher clearance rates on the protein material and lower clearance rates on the humic material.

Table 2. Oikopleura dioica. Estimated (mean $\pm \mathrm{SE}$ ) clearance rates $\left(\mathrm{ml}\right.$ ind.$\left.^{-1} \mathrm{~d}^{-1}\right)$ of fluorescent dextran tracers and natural humic and protein material in $>30 \mathrm{kDa}$ fraction. Average rates determined from 5 min grazing experiments $(\mathrm{n}=6)$ in laboratory using individuals with average trunk length (TL) of 700 to $710 \mu \mathrm{m}$. nd: not calculated as no significant clearance detected

\begin{tabular}{|c|c|c|c|c|c|c|c|}
\hline \multirow[t]{2}{*}{ Expt } & \multirow[t]{2}{*}{$\mathrm{TL}(\mu \mathrm{m})$} & \multicolumn{4}{|c|}{ — Dextran con. } & \multicolumn{2}{|c|}{ Material in $>30 \mathrm{kDa}$ fraction } \\
\hline & & $3 \mathrm{kDa}$ & $10 \mathrm{kDa}$ & $40 \mathrm{kDa}$ & $70 \mathrm{kDa}$ & Humic & Protein \\
\hline Tracer 1 & $710 \pm 10$ & $28.9 \pm 3.1$ & & $28.4 \pm 1.8$ & & & \\
\hline Tracer 2 & $710 \pm 5$ & & $55.1 \pm 2.7$ & & nd & & \\
\hline >30 kDa natural CDOM & $700 \pm 8$ & & & & & $0.5 \pm 0.02$ & $8.5 \pm 1.3$ \\
\hline
\end{tabular}




\section{DISCUSSION}

\section{Source and sink of CDOM}

Relatively little is known about biological sources or sinks of chromophoric dissolved organic material (CDOM). Bacteria and phytoplankton have been pro-
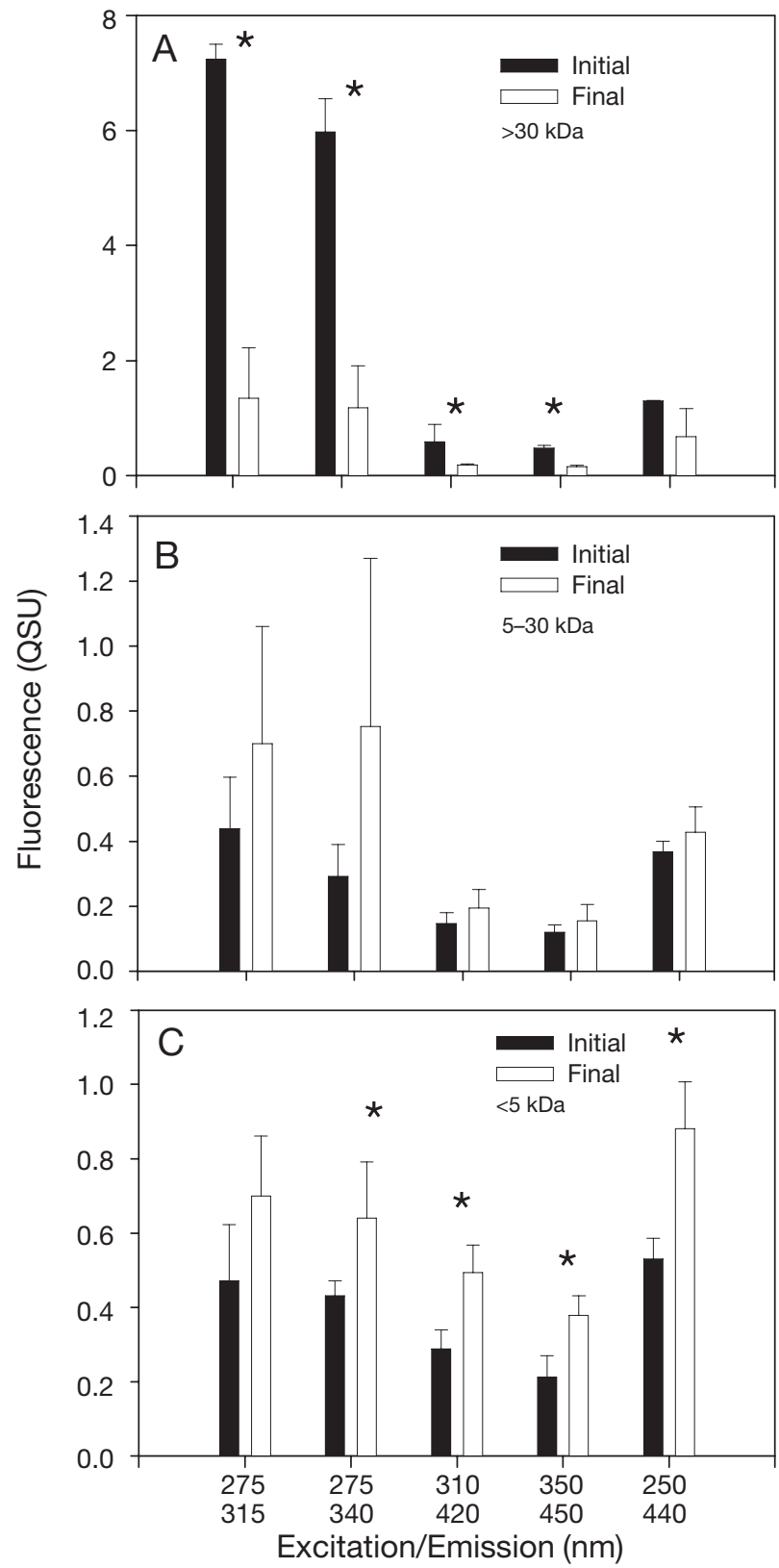

Fig. 7. Oikopleura dioica. Appendicularian was incubated for 5 min with different molecular size fractions of naturally occurring CDOM to determine if it could clear CDOM. (A) In $>30 \mathrm{kDa}$ fraction, significant $\left({ }^{*} \mathrm{p}<0.05\right.$; Student's $t$-test $)$ removal of humic and protein fractions occurred; (B) 5 to $30 \mathrm{kDa}$ fraction, no significant differences were found between initial and final water; (C) in $<5 \mathrm{kDa}$ fraction, significant $\left({ }^{*} \mathrm{p}<0.05\right)$ input occurred in humic and protein fractions posed as potential sources of CDOM (Carder et al. 1989, Nelson et al. 1998), and recently zooplankton have been shown to be sources of CDOM (Steinberg et al. 2004, Urban-Rich et al. 2004). However, bacteria have been considered to be the only biological organisms that can utilize and degrade CDOM (Moran et al. 2000). The results of our study clearly show that Oikopleura dioica is not only a source of CDOM, but can also be a means of removing CDOM from seawater (Figs. 3 \& 7).

The importance of oikopleurids as a source or removal mechanism of CDOM may vary with season and location depending upon the food-web structure. Oikopleura dioica is a widely distributed coastal species reported from a diversity of environments, including many coastal regions of the North Atlantic Ocean, the Mediterranean Sea, the South Atlantic Ocean, the Gulf of Mexico and the Pacific Ocean (reviews in Fenaux 1998, Fernandez \& Acuna 2003). O. dioica generally occurs seasonally, and during blooms when it is still actively feeding, it has been reported at concentrations ranging from 20 to 53 ind. $\mathrm{l}^{-1}$ (Dagg 1995, Fernandez \& Acuna 2003). During nonbloom conditions, larvaceans are generally found at concentrations of 0.1 to 0.5 ind. $1^{-1}$ (Fenaux 1998). During periods of maximum abundance, which can last for a day to several weeks they have the potential to significantly affect the optical characteristics of the water in many marine environments through their clearance and release of CDOM.

\section{DOM cycling by oikopleurids}

The results of this study indicate that Oikopleura dioica can influence the size distribution of DOM, and thus potentially DOM cycling along with optical water characteristics, by modifying CDOM size distribution. $O$. dioica can clear and ingest DOM in the 10 to $40 \mathrm{kDa}$ range, but excretes material in the $<30 \mathrm{kDa}$ range, primarily in the $<5 \mathrm{kDa}$ region (Fig. 3). The efficiency of DOM ingestion and the mechanisms by which it is ingested are unknown. Larvaceans feed by pumping water through an elaborate gelatinous house consisting of several filters (Deibel et al. 1985, Deibel \& Powell 1987). During this process, matter is concentrated to levels up to $1000 \times$ higher than ambient levels. It is possible that the DOM coagulates and thus increases to a size at which it is able to be retained by the larvaceans, filter (filter pore-size $=0.2 \mu \mathrm{m}$ ). Another possibility is that the DOM is cleared by direct interception and adhesion to the filter mesh. However, the lack of significant tracer on the empty houses suggests that adhesion to the house (and presumably subsequent adhesion to the filter apparatus) is not an overly important path of DOM removal. Another possibility is diffusion- 
deposition which is governed by Brownian movement. As smaller particles move more than large particles, they would be more likely to connect with the filter or to randomly coagulate with another particle, thus becoming large enough to be filtered by the larvacean. Again, the lack of significant amounts of tracer on the empty houses suggests that diffusion-deposition alone is not important. However, diffusion-deposition combined with the pumping of water by the larvacean could prove important. This process could not be determined during this study.

Marine humic matter is characteristically of low molecular weight and low aromaticity (Hedges 1992). Therefore, the finding that Oikopleura dioica excretes marine humic material of low molecular weight is not surprising. It is not clear if all DOM released by $O$. dioica is of small molecular weight, or if this applies to the CDOM fraction only. In the few studies that have examined the size distribution of DOM released by grazing zooplankton or flagellates, large, high molecular weight DOC or colloidal material has been the dominant form of DOM (Tranvik 1994, Strom et al. 1997). In most copepod grazing experiments, increased bacterial numbers and activity are recorded, and are attributed to the release of DOC by the grazing copepods, however in our grazing study with O. dioica bacterial numbers declined, most probably due to consumption by the larvaceans. Thus, the turnover and fate of DOM and its role in the microbial loop may differ as a function of zooplankton community-structure.

The clearance rates measured in this study for the fluorescent dextran tracers were in the same range as measured for Oikopleura dioica on particles (Fenaux \& Malara 1990, Bedo et al. 1993); however, the clearance rates on natural CDOM were 3 to 100 times lower. This difference in clearance rates could be due to variations in concentrations of the material or in the intrinsic properties of the DOM. Humic material may not coagulate into larger aggregates as easily as carbohydrates. Carbohydrates and proteins are known to be adhesive, which could increase their aggregation potential. The almost 20 times greater clearance rates of the protein compared to the humic material suggests that properties of the DOM influence the retention efficiency and thus clearance rate of DOM size classes by oikopleurids. Thus, grazing by $O$. dioica leads to a differential cycling of DOM pools, based on both the size of the molecules as well as its chemical composition.

To our knowledge, the relationship between oikopleurids and dissolved organic matter (DOM) has not been investigated earlier. In a parallel study, it was shown that Oikopleura dioica excretes CDOM (J. Urban-Rich et al. unpubl. data). Results from our grazing experiments support the excretion results, and indicate that $O$. dioica excretes primarily small molec- ular weight $\mathrm{CDOM}<5 \mathrm{kDa}$, while consuming the larger $>10 \mathrm{kDa}$ fraction. This interesting interaction between ingestion and excretion has important implications for total DOM cycling as well as for CDOM cycling. Terrestrially derived humic and fulvic acids tend to be of high molecular weight, with a higher degree of aromaticity than marine humic and fulvic acids. O. dioica would seem to be able to clear and ingest terrestrially derived CDOM, and either assimilate or repackage it into fecal pellets. While most of the DOM is of low molecular weight, much of the recalcitrant DOM in the oceans is of high molecular weight, HMW (Carlson 2002), and in estuaries and coastal environments HMW DOM is also added to by rivers (Cauwet 2002). Thus O. dioica may play an important role in DOM cycling, especially in coastal environments. Since oikopleurids can form short and direct trophic links between their food and higher trophiclevel organisms predators, including commercial fishes (Nedreaas 1987, Shimamoto \& Watanabe 1994) and other gelatinous zooplankton (Larson 1991), they could transfer DOM up the food web.

\section{Implications of oikopleurid grazing on CDOM}

CDOM is a significant but variable portion of the total DOM pool that has the capability of absorbing light in both the ultraviolet and visible regions, thus influencing the amount of photosynthetically available radiation that reaches the phytoplankton (Arrigo \& Brown 1996). Therefore, processes that remove CDOM promote water clarity and biological production, while processes that add CDOM reduce the water clarity and decrease primary production. Oikopleurids appear to be one of the unique biological organisms that contribute to both processes. We estimated the grazing impact of Oikopleura dioica on CDOM in the Bay of Biscay as follows: assuming an abundance of 15 O. dioica $\mathrm{l}^{-1}$ (Fernandez \& Acuna 2003), a measured clearance rate of $0.5 \mathrm{ml} \mathrm{d}^{-1}$, and a fluorescent CDOM concentration of $40 \mathrm{QSU}^{-1}$, O. dioica would clear $\sim 18 \% \mathrm{CDOM} \mathrm{d}^{-1}$, assuming that all CDOM at ex/em $355 / 450 \mathrm{~nm}$ was $>30 \mathrm{kDa}$. However, if only a portion of the CDOM were in the large size range, then clearance rates for this fraction could be much higher than $18 \%$. This estimate suggests that under certain conditions (i.e. in areas in which CDOM is comprised of the large size fraction) oikopleurids could play an important role by clearing the water. The measured clearance rate in our experiments was substantially below laboratory and field clearance rates on particles, which range from 22 to $210 \mathrm{ml} \mathrm{d}^{-1}$ (Bedo et al. 1993, López-Urrutia et al. 2003). This reflects the reduced effectiveness of O. dioica in clearing DOM compared to clearing parti- 
cles. However it can still remove a substantial portion of the DOM, and more importantly, affect the size distribution of the DOM. In our grazing experiment on natural seawater, CDOM absorption at $355 \mathrm{~nm}$ (Fig. 1) increased, suggesting that excretion exceeded grazing in this instance. However, the size distribution of the CDOM also changed, which could affect the turnover of the CDOM pool and thus the water color.

This study has shown that Oikopleura dioica can clear CDOM from seawater. Grazing plus excretion by this oikopleurid changes the size distribution of the $\mathrm{CDOM}_{i}$ this could affect its role in the water column in relation to determining ocean color and/or in the complex of trace metals and pollutants. In addition, grazing by $O$. dioica results in differential cycling of the DOM pool based on both the molecular size of the material and on its chemical composition. The importance of this larvacean in DOM cycling needs to be investigated. The present experiments suggest that oikopleurids can alter the molecular size distribution of DOM, thus influencing organic matter cycles as well as water color.

Acknowledgements. We thank James McCarty for his help in conducting experiments and processing the fluoremetric samples, Rachel Ruppel for her help in processing the absorption samples, Marcos Lopez for his help in culturing the oikopleurids and Dr. Bob Chen at the University of Massachusetts Boston for loaning us his spectrophotometer. This work was supported by an Office of Naval Research Grant (ONR -N000014-01-1-0247) to J.U.R.

\section{LITERATURE CITED}

Acuña JL, Kiefer M (2000) Functional response of the appendicularian Oikopleura dioica. Limnol Oceanogr 45:608-618

Alldredge AL (1977) House morphology and mechanisms of feeding in the Oikopleuridae (Tunicata, Appendicularia). J Zool 181:175-188

Arrigo KR, Brown CW (1996) Impact of chromophoric dissolved organic matter on UV inhibition of primary productivity in the sea. Mar Ecol Prog Ser 140:207-216

Bedo AW, Acuña JL, Robins D, Harris RP (1993) Grazing in the micronic and sub-micronic particle size range: the case of Oikopleura dioica (Appendicularia). Bull Mar Sci 53:2-14

Blough NV, Zafirou CC, Bonilla J (1993) Optical absorption spectra of waters from the Orinoco river outflow: terrestrial input of colored organic matter to the Caribbean. J Geophys Res 98:2271-2278

Carder KL, Steward RG, Harvey GR, Ortner PB (1989) Marine humic and fulvic acids: their affects on remote sensing of ocean chlorophyll. Limnol Oceanogr 34:68-81

Carlson CA (2002) Production and removal processes. In: Hansell DA, Carlson CA (eds) Biogeochemistry of marine dissolved organic matter. Academic Press, San Diego, CA p 91-152

Cauwet G (2002) DOM in the coastal zone. In: Hansell DA, Carlson CA (eds) Biogeochemistry of marine dissolved organic matter. Academic Press, San Diego, CA, p 579-611

Coble PG (1996) Characterization of marine and terrestrial DOM in seawater using excitation-emission matrix spectroscopy. Mar Chem 51:325-346
Coble PG, Schultz CA, Mopper K (1993) Fluorescence contouring analysis of DOC intercalibration experiment samples: a comparison of techniques. Mar Chem 41:173-178

Dagg MJ (1995) Copepod grazing and the fate of phytoplankton in the northern Gulf of Mexico. Cont Shelf Res 15: 1303-1317

Deibel D, Powell CBL (1987) Ultrastructure of the pharyngeal filter of the appendicularian Oikopleura vanhoeffeni: implications for particle size selection and fluid mechanics. Mar Ecol Prog Ser 35:243-250

Deibel D, Dickson ML, Powell CBL (1985) Ultrastructure of the mucous feeding filter of the house of the appendicularian Oikopleura vanhoeffeni. Mar Ecol Prog Ser 27:79-86

De Souza Sierra MM, Donard OFX, Lamotte M (1997) Spectral identification and behavior of dissolved organic fluorescent material during estuarine mixing processes. Mar Chem 58:51-58

Fenaux R (1998) The classification of Appendicularia. In: Bone Q (ed) The biology of pelagic tunicates. Oxford University Press, New York, p 295-308

Fenaux R, Gorsky G (1985) Nouvelle technique d'élevage des appedniculaires. Rapp P-V Réun Commi Int Mer Méditerr 29:291-292

Fenaux R, Malara G (1990) Taux de filtration de l'appendiculaire Oikopleura dioica Fol 1872. Rapp P-V Réun Comm Int Explor Sci Mer Méditerr 32:20

Fernandez D, Acuña JL (2003) Enhancement of marine phytoplankton blooms by appendicularian grazers. Limnol Oceanogr 48:587-593

Flood PR (1991) Architecture of, and water circulation and flow rate in the house of the planktonic tunicate Oikopleura labradoriensis. Mar Biol 111:95-111

Flood PR, Deibel D, Morris C (1992) Filtration of colloidal melanin from sea water by planktonic tunicates. Nature 355:630-632

Gorsky G, Fenaux R (1998) The role of appendicularians in marine food webs. Bone $\mathrm{Q}$ (ed) The biology of pelagic tunicates. Oxford Press, New York, p 161-170

Green SA, Blough NV (1994) Optical absorption and fluorescence properties of chromophoric dissolved organic matter in natural waters. Limnol Oceanogr 39:1903-1916

Hedges J (1992) Global biochemical cycles: progress and problems. Mar Chem 39:67-93

Hobbie JD, Daley RJ, Jasper S (1977) Use of Nuclepore filters for counting bacteria by fluorescence microscopy. Appl Environ Microbiol 33:1225-1228

Larson RJ (1991) Diet prey selection and daily ration of Stomolomphus meleagris, a filter feeding scyphomedusa from the NE Gulf of Mexico. Estuar Coast Shelf Sci 32:511-525

López-Urrutia A, Acuña JL, Irigoien X, Harris R (2003) Food limitation and growth in temperate epipelagic appendicularians (Tunicata). Mar Ecol Prog Ser 252:143-157

McKnight DM, Boyer EW, Westerhoff PK, Doran PT, Kulbe T, Andersen DT (2001) Spectrofluorometric characterization of dissolved organic matter for indication of precursor organic material and aromaticity. Limnol Oceanogr 46: $38-48$

Moran MA, Sheldon WM, Zepp RG (2000) Carbon loss and optical property changes during long term photochemical and biological degradation of estuarine dissolved organic matter. Limnol Oceanogr 45:1254-1264

Morris CC, Deibel D (1993) Flow rate and particle concentration within the house of the pelagic tunicate Oikopleura vanhoeffeni. Mar Biol 115:445-452

Nedreaas K (1987) Food and feeding habits of young saithe, Pollachius virens, on the coast of western Norway. Fiskeridir Skrift Ser Fisk 18:263-301 
Nelson NB, Seigel DA, Michaels AF (1998) Seasonal dynamics of colored dissolved organic material in the Sargasso Sea. Deep-Sea Res I 45:931-957

Shimamoto N, Watanabe J (1994) Seasonal changes in feeding habit of red sea bream Pagrus major in the eastern Set Inland sea, Japan. Bull Jpn Soc Sci Fish 60:65-71

Skoog A, Wedborg M, Fogelqvist E (1996) Photobleaching of fluorescence and the organic carbon concentration in a coastal environment. Mar Chem 55:333-345

Steinberg DK, Nelson NB, Carlson CA, Prusak, A (2004) Production of chromophoric dissolved organic matter (CDOM) in the open ocean by zooplankton and the colonial cyanobacterium Trichodesmium spp. Mar Ecol Prog Ser 267:45-56

Editorial responsibility: Otto Kinne (Editor-in-Chief), Oldendorf/Luhe, Germany
Strom SL, Benner R, Dagg MJ (1997) Planktonic grazers are a potentially important source of marine dissolved organic carbon. Limnol Oceanogr 42:1364-1374

Tranvik L (1994) Colloidal and dissolved organic matter excreted by a mixotrophic flagellate during bacterivory and autotrophy. Appl Environ Microbiol 60:1884-1888

Urban-Rich J, McCarty JT, Shailer M (2004) Effects of food concentration and diet on chromophoric dissolved organic matter accumulation and fluorescent composition during grazing experiments with the copepod Calanus finmarchicus. ICES J Mar Sci 61:542-551

Zimmerman JTF, Rommets JW (1974) Natural fluorescence as a tracer in the Dutch Wadden Sea and the adjacent North Sea. Neth J Sea Res 8:117-125

Submitted: May 6, 2003; Accepted: September 1, 2005

Proofs received from author(s): July 5, 2006 